\title{
Importance of diurnal variations on clinical value and interpretation of serum urate measurements
}

\author{
M S Devgun, H S Dhillon
}

\begin{abstract}
Aim: To show the extent of diurnal variations in serum urate concentration and the possible consequences on the clinical interpretation.

Methods: Nineteen controls and 40 patients took part in this study. Preliminary investigations on selected subjects provided blood samples at regular intervals between the hours of 0800 and 2300 hours. From these observations the timing of venepuncture for the remaining subjects was chosen at 0800-0900 hours, with a second sample taken between 1700 and 1800 hours. Analytical quality was monitored using quality control procedures and all samples were analysed in a single batch to minimise errors.

Results: All subjects, except some hypertensive elderly women, showed a diurnal rhythm. The mean serum urate value between $0800-0900$ hours was higher than that observed between 1700-1800 hours. A decrease of up to $30 \%$ was observed in a group of diabetic patients. Nine subjects in the study had hyperuricaemia in the morning, but only six in the afternoon, indicating the requirement of a reference interval that takes account of diurnal variations.

Conclusion: When studying the temporal relation for the medical importance, or when attempting to interpret the serum urate concentration, it is important to consider the diurnal rhythms of this analyte.
\end{abstract}

Hyperuricaemia can be caused by excessive intake of dietary purines, increased de novo synthesis (primary gout and Lesch-Nyhan syndrome), increased endogenous nucleic acid catabolism (chronic myeloid leukaemia and polycythemia vera), and when there is a reduced renal excretion of urate (renal failure, use of diuretics, and diseases resulting in acidosis). ${ }^{12}$ Hyperuricaemia is defined as a serum value greater than the laboratory's reference interval. The urate reference interval depends on age, sex, weight, exercise, diet, prolonged fasting and season; racial differences are also important. ${ }^{3-6}$ If a serum analyte shows a diurnal variation this may have a major impact on the interpretation of laboratory results-for example, as is the case when measuring serum cortisol concentrations.

Previous studies on diurnal variations of serum urate in normal subjects have produced a discordant set of observations. These include no diurnal rhythms ${ }^{7}$ or diurnal rhythms with a raised morning concentration. ${ }^{89}$ The aim of our study was to further investigate this important point as it may significantly affect the interpretation of hyperuricaemia and may also highlight the importance of temporal changes when monitoring disease and treatment. Not only apparently normal subjects but a selected group of patients were also investigated.

\section{Methods}

Fifty nine subjects were studied. The subjects were split into four groups: (a) control group; (b) diabetic patients; (c) pregnant women with and without hypertension; and (d) a group of elderly patients with hypertension. Control subjects comprised a group of medical students, 11 men and eight women, with an age range of 20 to 30 years. Diabetic patients, 15 males and three females, were in the age range 15 to 32 years. The age range of the 14 pregnant women was 22 to 39 ; eight of these were classed as hypertensive and six as normotensive pregnancies. Hypertension was defined as a blood pressure of more than $140 / 90 \mathrm{mmHg}$ systolic/ diastolic, respectively, on two or more occasions. The remaining hypertensive group comprised four men and four women with an age range of 60 to 80 years.

Blood samples were provided by all subjects over a period of six weeks between February and March to avoid any seasonal variations. For the purpose of this study specimens were taken between 0800 and 0900 hours and then between 1700 and 1800 hours; although latter samples could have been taken at any time after 1100 hours (table 1). The timings of blood samples were chosen from our preliminary observations (table 1) obtained from a series of venepunctures on a selected number of subjects between 0800 and 2400 hours. Pregnant

Table 1 Preliminary set of observations on serum urate in four male control subjects showing significant differences between 0900 and 2100 hours $(t=6.36 ; p<0.008)$

\begin{tabular}{ll}
\hline & \multicolumn{2}{c}{ Serum urate $(\mu \mathrm{mol} / \mathrm{l})$} \\
\cline { 2 - 2 } Time & Mean $(S D)$ \\
\hline 0900 & $364(26)$ \\
1100 & $345(33)$ \\
1300 & $320(48)$ \\
1500 & $310(28)$ \\
1700 & $300(29)$ \\
1900 & $307(26)$ \\
2300 & $311(22)$ \\
\hline
\end{tabular}


Table 2 Stability of serum urate at $4^{\circ} \mathrm{C}$ and at $22^{\circ} \mathrm{C}$ using quality control sera

\begin{tabular}{|c|c|c|c|}
\hline & \multirow[b]{2}{*}{ No } & \multicolumn{2}{|c|}{ Serum urate ( $\mu$ mol $/ l)$} \\
\hline & & Low & High \\
\hline $\begin{array}{l}\text { Fresh sample } \\
1 \text { day at } 4^{\circ} \mathrm{C} \\
3 \text { days at } 4^{\circ} \mathrm{C} \\
4 \text { days at } 4^{\circ} \mathrm{C}\end{array}$ & $\begin{array}{l}33 \\
17 \\
17 \\
18\end{array}$ & $\begin{array}{ll}210 & (10) \\
210 & (10) \\
210 & (10) \\
180 & (10)\end{array}$ & $\begin{array}{ll}660 & (10) \\
650 & (10) \\
650 & (10) \\
610 & (10)\end{array}$ \\
\hline $\begin{array}{l}1 \text { day at } 22^{\circ} \mathrm{C} \\
2 \text { days at } 22^{\circ} \mathrm{C}\end{array}$ & $\begin{array}{l}16 \\
17\end{array}$ & $\begin{array}{l}240(10) \\
130(120)\end{array}$ & $\begin{array}{ll}750 & (10) \\
990 & (270)\end{array}$ \\
\hline
\end{tabular}

women and elderly hypertensive subjects provided a morning and an afternoon sample for urate measurements. Blood from the remaining subjects were taken, with the number of samples ranging from eight to 13 each.

Serum uric acid was determined within 24 hours of venepuncture, or stored frozen at $-23^{\circ} \mathrm{C}$ until analysis. Frozen specimens are quite stable for at least six months. ${ }^{10}$ Measurements were made by a uricase-catalase method $\left(340 \mathrm{~nm}, 37^{\circ} \mathrm{C}\right)$ on a centrifugal analyser (Rotochem IIa, Aminco-Bowman, USA). All samples from any one individual were analysed in a single batch to minimise variability of results. Each batch of urate was monitored with a freshly prepared quality control serum. Interbatch variation and stability of samples were also assessed by using quality control procedures.

\section{Results}

Imprecision of our measurements at low and high concentrations (200 and $610 \mu \mathrm{mol} / 1$, respectively) for inter- and intrabatch was $<0.08 \%$. Investigations of sample stability are shown in table 2. Samples are stable for three days only when stored at $4^{\circ} \mathrm{C}$; this agrees with previous findings. ${ }^{10}$ Samples left at room temperature for 24 hours gave significantly higher levels $(t=2.60 ; \mathrm{p}<0.01)$.

Overall statistical assessment of all the subjects, using the paired $t$ test, showed a diurnal rhythm with a mean urate concentration between 0800 and 0900 hours that was significantly greater than that between 1700 and 1800 hours $(t=3.67 ; p<0.01)$. In normotensive pregnant women and elderly subjects, however, this was not apparent (table
Table 4 Number of hyperuricaemic subjects in relation to time of venepuncture

\begin{tabular}{lll}
\hline & \multicolumn{2}{l}{ No of subjects } \\
\cline { 2 - 3 } & $a m$ & $p m$ \\
\hline $\begin{array}{lll}\text { Control subjects: } \\
\text { Males } \\
\text { Females }\end{array}$ & 2 & 1 \\
$\begin{array}{l}\text { Pregnant: } \\
\text { Normotensive } \\
\quad \text { Hypertensive }\end{array}$ & 1 & 0 \\
$\begin{array}{l}\text { Elderly hypertensive: } \\
\quad \text { Males }\end{array}$ & 1 & 1 \\
$\quad$ Females & 2 & 2 \\
\hline
\end{tabular}

3). Two normotensive pregnant women, and two people from each of the elderly hypertensive male and female group showed afternoon values that were slightly higher than the morning values $(8.4(2.4) \%)$. All these patients were receiving multiple drugs, some including diuretics. The mean percentage fall $(28 \%)$ was higher in diabetics compared with the other groups $(8-15 \%)$. The range of values found in all groups was highly variable (0-58\%).

Of the 59 subjects studied, five women and four men were found to have hyperuricaemia in the morning (table 4) as defined by our reference interval-that is, females $120-340$ $\mu \mathrm{mol} / 1$ and males $200-390 \mu \mathrm{mol} / 1$, respectively. Three people from this group (23\%), one female and two males, would not have been classed as hyperuricaemic in the afternoon. None of these subjects had diabetes, and no subject was hyperuricaemic between 1700 and 1800 hours if that subject was normouricaemic at 0800 and 0900 hours. Table 5 shows serial variations in serum urate concentration in a group of diabetic patients. The mean (SEM) change between 1000 and 2000 hours was $27 \cdot 1$ $(2.4) \%$ when compared with values found at 0800 hours. A gradual and significant fall was seen to occur until 1100 hours, but no significant differences occurred between 1100 and 2000 hours $(t=0.44 ; \mathrm{p}>0.35)$.

\section{Discussion}

There are large variations in serum urate from one person to another and from one day to another $^{381112}$ as a result of dietary purines, exercise, etcetera. ${ }^{13}$ The ratio ( $R$ value) of

Table 3 Mean (SD) values and percentage changes in serum urate between 0800-0900 and between 1700 and 1800 hours

\begin{tabular}{|c|c|c|c|c|c|c|}
\hline \multirow[b]{2}{*}{ Group } & \multirow[b]{2}{*}{$N$} & \multicolumn{2}{|c|}{ Serum urate ( $\mu \mathrm{mol} / \mathrm{l})$} & \multicolumn{2}{|c|}{ Change \% } & \multirow[b]{2}{*}{ p Value } \\
\hline & & $a m$ & $p m$ & Mean & Range & \\
\hline $\begin{array}{l}\text { Control subjects: } \\
\text { Males } \\
\text { Females }\end{array}$ & $\begin{array}{r}11 \\
8\end{array}$ & $\begin{array}{l}346(53) \\
266(46)\end{array}$ & $\begin{array}{l}317(63) \\
227(47)\end{array}$ & $\begin{array}{r}-8 \cdot 4 \\
-14 \cdot 7\end{array}$ & $\begin{array}{l}0-39 \\
7-28\end{array}$ & $\begin{array}{l}<0.02 \\
<0.001\end{array}$ \\
\hline $\begin{array}{l}\text { Pregnant: } \\
\text { Normotensive } \\
\text { Hypertensive }\end{array}$ & $\begin{array}{l}6 \\
8\end{array}$ & $\begin{array}{l}257(96) \\
301(99)\end{array}$ & $\begin{array}{l}230(86) \\
269(94)\end{array}$ & $\begin{array}{l}-10.5 \\
-10.6\end{array}$ & $\begin{array}{l}4-58 \\
3-29\end{array}$ & $\begin{array}{l}>0.62 \\
<0.001\end{array}$ \\
\hline $\begin{array}{l}\text { Elderly hypertensive } \\
\text { Males } \\
\text { Females }\end{array}$ & $\begin{array}{l}4 \\
4\end{array}$ & $\begin{array}{l}365(42) \\
280(70)\end{array}$ & $\begin{array}{l}360(35) \\
290(65)\end{array}$ & $\begin{array}{l}-1.4 \\
+3.6\end{array}$ & $\begin{array}{l}3-19 \\
-2 \text { to }+14\end{array}$ & $\begin{array}{l}>0.76 \\
>0.34\end{array}$ \\
\hline $\begin{array}{l}\text { Diabetic: } \\
\text { Males } \\
\text { Females }\end{array}$ & $\begin{array}{r}15 \\
3\end{array}$ & $\begin{array}{l}253(64) \\
245(25)\end{array}$ & $\begin{array}{l}182(63) \\
135(20)\end{array}$ & $\begin{array}{l}-28.0 \\
-44.9\end{array}$ & $\begin{array}{l}10-37 \\
18-31\end{array}$ & $\begin{array}{l}<0.001 \\
<0.001\end{array}$ \\
\hline
\end{tabular}


Table 5 Diurnal variations in serum urate concentration in 11 diabetic patients

\begin{tabular}{|c|c|c|}
\hline \multirow[b]{2}{*}{ Time } & \multicolumn{2}{|c|}{ Serum urate $(\mu \mathrm{mol} / \mathrm{l})$} \\
\hline & Mean (SD) & $\%$ Change \\
\hline $\begin{array}{l}0800 \\
0900 \\
1000 \\
1100 \\
1200 \\
1300 \\
1400 \\
1500 \\
1600 \\
1700 \\
1800 \\
1900 \\
2000\end{array}$ & $\begin{array}{ll}250 & (66) \\
235 & (67) \\
209 & (62) \\
188 & (59) \\
196 & (59) \\
186 & (71) \\
182 & (67) \\
173 & (46) \\
177 & (57) \\
181 & (77) \\
193 & (64) \\
183 & (66) \\
173 & (55)\end{array}$ & $\begin{array}{l}-6.0 \\
-16.4 \\
-28.2 \\
-21.6 \\
-25.6 \\
-27.2 \\
-30.8 \\
-29.2 \\
-27.6 \\
-22.8 \\
-26.8 \\
-30.8\end{array}$ \\
\hline
\end{tabular}

individual variance to that of group variance for urate has been described as $<0.9 .^{314}$ The reference interval is therefore almost always an insensitive index of significant changes for any particular individual. Our results seem to show that such a low $\mathbf{R}$ value for serum urate may also result from diurnal variations apart from the factors described above. In most of our subjects the critical period when a significant change in serum urate value occurred was after 1100 hours, with a smaller change occurring between 1100 and 1200 hours. The extent of changes observed was very large, confirming a pattern reported by Hill and coworkers ${ }^{15}$ in their study of pregnant women. Daily monitoring of serum urate in pre-eclamptic pregnancies therefore ought to be at a time of the day when serum value is least likely to be affected by the diurnal rhythm. Otherwise, vital biochemical information for interpretation and monitoring is likely to be absent, limiting the usefulness of this analyte. Diurnal variation was observed in all our groups except in a small group of elderly subjects and pregnant women. This agrees with the observations of Statland and coworkers ${ }^{7}$ in their limited study of three control subjects. The lack of diurnal variation in a small group of our subjects could easily be accounted for by their medication which also included diuretics. ${ }^{13}$

The reversal of the rhythm in eight of our subjects, all except one, occurred in hypertensive elderly patients, and may be related to the biphasic response phenomenon of drug dosages $^{2}$ or to the administration of other treatment. Untreated hypertensive patients have high serum urate, and the prevalence $(67 \%)$ of hyperuricaemia further increases with treatment. ${ }^{16}$ Hyperuricaemia in both essential and renal hypertension is secondary to the raised blood pressure. It is not known whether the loss of diurnal rhythm predisposes these subjects to development of symptomatic gout or deterioration of renal function. Our observations also show that as a group the largest fall due to diurnal rhythm was observed in diabetic patients, even though all of them were well within the reference interval. This may be related to the use of hypoglycaemic agents or to the glycaemic control of these patients.

Imprecision of laboratory measurements was minimal, and therefore the possibility of errors due to analytic procedures was small. The quality of control sera was poor after three days of storage. Evaporation of specimen may to some extent be responsible for this. Other factors may include: specimen matrix with differing enzyme systems occurring in mammals-that is, artiodactyl sera (bovidae family) as opposed to primate sera (hominidae family); an increase in $\mathrm{pH}$ with storage $^{17}$ and the resulting effects on the solubility of uric acid. ${ }^{1}$ Multienzyme analytic methods are also known to be prone to interference; in our case ethanol converting enzymes may have been affected. These observations show that quality control serum deteriorates rapidly at room temperature. Unless such specimens are kept at $4^{\circ} \mathrm{C}$ a freshly reconstituted preparation should be used each time.

There are numerous reports, with a discordant set of results, of drugs such as atenolol, captopril, ascorbate and hydrochlorthiazide purportedly causing either raised, lowered, or unchanged serum urate. ${ }^{18}$ In view of the much higher magnitude of changes observed in this study such reports would need to be cautiously interpreted. As shown here, the rate of detection of hyperuricaemia was related to the time of the day the specimen was taken. Whether one should measure serum urate at its peak or at its trough level is difficult to answer. From the lower variability seen among subjects in the afternoon it would seem appropriate to recommend sampling after 1100 hours when monitoring disease or the effectiveness of treatment. It would be more appropriate, however, to perform venepuncture between 0800 and 0900 hours if the increased renal tubular load of urate were to predispose to impaired renal function. In each case all laboratories would need to have established appropriate sets of reference intervals for making pertinent comments on laboratory results and of their relevance for medical treatment. This becomes even more of a necessity if no previous data are available for a particular patient.

We thank all participants for taking part in this study, and Dr T Isles for providing samples obtained from his diabetic patients.

1 Conger JD. Acute uric acid nephropathy. Med Clin North Am 1990;74:859-71.

2 Cameron JS, Simmonds HA. Uric acid, gout and the kidney. $J$ Clin Pathol 1981;34:1245-54.

3 McLauchlan DM, Gowenlock AH. The "normal range"reference values. In: Gowenlock AH, McMurray JR McLauchlan DM, eds. Varley's practical clinical biochemistry. London: Heinemann, 1988:273-84.

4 Statland BE, Winkel P, Bokelund H. Factors contributing to intra-individual variation of serum constituents: 2 . Effects f exercise and diet on variation of serum constituents in healthy subjects. Clin Chem 1973;19:1380-3.

5 Becker KL, Goldstein RA. Hyperuricaemia in healthy men: intermittent elavations and the effects of sunlight. $A m$ Clin Nutr 1972;25:453.

6 MacLauchlan MJ, Rodnan GP. Effects of food, fasting and alcohol on serum uric acid and acute attacks of gout. $A m J$ alcohol on serum uric

7 Statland $B E$, Winkel $P$, Bokelund $H$. Factors contributing to intra-individual variation of serum constituents: 1. intra-individual variation of serum constituents: 1 . Within-day variation of serum const

subjects. Clin Chem 1973;19:1374-9. Morrison B, Shenkin A, McLelland A, et al. Intra-
individual variation in commonly analysed serum con-

9 Kellar H, Colombo JP. Nucleic acid metabolism-Uric acid. In: Richterich R, Colombo JP, eds. Clinical chemistryTheory, practice and interpretation. Chichester: John Wiley, 1981:451-9. 
10 Schultz AL. Uric acid. In: Kaplan LA, Pesu AJ, eds. Clinical chemistry-Theory, analysis and correlation. 2nd edn. S Louis: CV Mosby, 1989:1024-8.

11 Costongs GMPJ, Janson PCW, Bas BM, et al. Short-term and long-term intra-individual variations and critical differences of clinical chemical laboratory parameters. $J$ Clin Chem Clin Biochem 1985;23:7-16.

12 Harris EK, Kanofsky P, Shakarji G, Cotlove E. Biological and analytic components of variation in long-term studies and analytic components of variation in long-term studies biological components of variation. Clin Chem 1970; 16:1022-7.

13 Scot JT. Food, drink, and gout. BMJ 1983;287:78-9.
14 Cotlove E, Harris EK, Williams GZ. Biological and analytic components of variation in long-term studies of serum constituents in normal subjects. III. Physiological and medical implications. Clin Chem 1970;12:1028-32.

15 Hill LM, Furness C, Dunlop W. Diurnal variation of serum urate in pregnancy. $B M J 1977 ; \mathrm{i}: 1520$.

16 Anonymos. Hypertension and uric acid. [Editorial]. Lancet $1981 ; \mathrm{i}: 365-6$.

17 Devgun MS. Delay in centrifugation and measurement of serum constituents in normal subjects. Clin Physiol Biochem 1989;7:189-97.

18 Young DS, Pestaner LC, Gibberman V. Effects of drugs on clinical laboratory tests. Clin Chem 1975;21:374D-7D. 